\title{
Development of Assessment Tools for Economic Activity of Regional Business
}

\author{
Rustam Ilkamovich Malikov \\ Irina Miniakhmetovna Sharipova \\ Vener Ilsurovich Kharisov \\ Gyuzel Gazimovna Sunaeva \\ Diana Daniyarovna Mukhametova
}

Ufa State University of Economics and Service, 145 Chernyshevsky st., Ufa, Republic of Bashkortostan, 450078, Russia

Doi:10.5901/mjss.2015.v6n5s2p434

\begin{abstract}
Under the conditions of traditional resources depletion, to ensure stable and sustainable economic development, the role of regional business is growing greatly as a prime investment and innovation factor and economic growth driver. To assess the positions of business structures, the indicators of production potential, innovation activity, welfare level of the regional population are used. Low economic activity of the Russian business is conditioned a lot by the fact that business structures came to be out of value added chain. The paper submitted offers the tools to assess business contribution to value added growth in a region, allowing to give recommendations on strategy of industrial and innovational development of a region. In the development course of governmental support measures and business regulation it is also feasible to assess business contribution in regional tax potential and revenue of regional budget.
\end{abstract}

Keywords: Gross value added, competitiveness, business, economic activity, budget efficiency.

\section{Introduction}

Currently, economic activity of regional business is becoming an important element of governmental policy aimed at harmonization of Russia's economic space, development of investment attractiveness of its constituent entities. Achievement of strategic stability in economy, prompt response to unfavorable changes in the economic environment depend not only on governmental economic control but rather on each business entity's initiative.

The opportunities of the existing business growth model in Russia have been used up. Global structural and technological shifts as well as strategic mistakes in macroeconomic policy were largely responsible for economy's growth rate reduction (gross domestic product growth was 1.3\% in 2013 and $0.6 \%$ in 2014), reduction of consumption, stagnation of investments in fixed assets, no accumulation of fixed capital in state-owned and private companies, deterioration of competitiveness of Russian goods, decrease in export of primary commodities.

Establishment of the conditions for sustainable harmonic economic development is important from the social welfare point of view, optimization of resources cost, high economic and ecological safety. Stable functioning and progressive development of economy is able to meet growing material and cultural requirements of country's and regions' population (Akhtarieva, 2014).

Economic development and growth are to a great extent ensured by business. As an important element of market economy business brings huge contribution in the growth of economic activity of regions and country. Importance of business is growing due to the appearance of new approaches and models of doing business (Ács, Autio, \& Szerb, 2014; Dragan, \& Isaic-Maniu, 2012; Anokhin, \& Schulze, 2009).

Our earlier research of business development disclosed the problems in connection with the increase of business contribution to ensure sustainable development of regional economy, finding and eliminating business development barriers, finding business risks (Solodilova, Malikov, \& Grishin, 2014; Sharipova, \& Mukhametova, 2014; Malikov, \& Kharisov, 2013).

Sufficient attention is paid to the study of theoretical and practical aspects of business's economic activity (Galindo, \& Méndez, 2014; Simón-Moya, Revuelto-Taboada, \& Guerrero, 2014; Toma, Grigore, \& Marinescu, 2014; Jennings, 
Greenwood, Lounsbury, \& Suddaby, 2013; Jones, Coviello, \& Tang, 2011; Kanniainen, \& Vesala, 2005; Eckhardt, \& Shane, 2003; Grishin, \& Arapov, 2013). To describe any progressive change, the terms development, growth are used, first of all, in connection with the economic sphere. In the event of a quantitative change of a parameter, it refers to economic growth, in the event of a qualitative change - to development scope change, structural changes, obtaining new characteristics by the economic system.

The economic indicators used in Russia are characterizing the dynamics of business activity change on national economy's level, for instance, business activity index AM- $\mathrm{b}$, business confidence index, business expectations index, etc. To assess regional business activity, industrial production index is mainly calculated, characterizing the situation in region's industry.

Business competitiveness is becoming a prime task of any government's industrial policy. Continuously changing situation in the contemporary society through technological innovations, geopolitical processes predetermines business transformation. Initially, being the basis of innovative, productive nature of economy, contributing to growing transparency of national economies, business due to its novelty is altering the nature of economy of any scale and level. New economic, information society alters traditional principles, approaches and models in connection with competitive business development as well as the tools for assessment of business activity and contribution to regional welfare.

Many researchers consider business competitiveness within value chain approach. That approach is used as a tool for markets and sectors analysis to work out recommendations on corporate competitiveness improvement on corporate and intercorporate levels and on the level of governmental and regional policies in connection with business support and development of market institutions (Kaplinskiy, 2002).

Domestic studies in that sphere were conducted based on separate sectors included in national or global value chains (Avdasheva, 2005).

Low economic activity of the Russian business is conditioned a lot by the fact that business structures came to be out of value added chain. The paper submitted offers the tools to assess of business contribution to cumulative value added in a region, allowing to give recommendations on strategy of region's industrial and innovational development.

Formation of new realities for business operation affects the system of assessment indicators of the condition and dynamics of regional economy's activity. The contemporary principles and models of successful business, transformation of business objectives and processes determine the need to assess business contribution to regional economies via its stake in value chains. Involvement in value chains is among the strategic imperatives of regional economic development. That ensures identification and realization of regional core competency.

Assessment of economic activity of business is one of the prime regional issues as the steps to be taken, development of priority kinds of production and activity spheres, social condition of a region and much more depend on the real view of regional economic system development.

\section{Methodology}

The term of economic activity of business characterizes first of all the feasibility of business entity's operation in connection with profit making on the basis of independent initiative, responsibility and innovational business idea.

It is generally accepted that business has especially active position in the market and innovational targeting. Business sector, due to its close relations with production, innovative, social spheres ensures economic activity of a region. It is seen that it's business which has material potential for growth of regional economic activity, capable to maintain stable growth rates of regional socio-economic development.

Large business forms the material basis of welfare and economic stability of any state. Concentrating and centralizing capital and other assets, large business is becoming a driving force in economy's restructuring. Small and medium business, due to deep specialization and cooperation, contributes to the expansion of economic potential of large enterprises. Small and medium business is capable to be engaged in venture projects, to employ people released by large business in the course of efficiency enhancement or liquidation of manufacturing facilities. Balanced development of large, small and medium business contributes to the development of competitive market environment and ensures availability of goods and services in the local consumer market and financial resources in the regional budget.

Throughout the world, much attention is paid to business development on national, regional and local levels. Support systems include both national strategies of state development in connection with business and separate programs on consulting, legal, informational, resource and financial support locally. Large projects promoting regional socio-economic development are realized through public-private partnership as interaction of business structures and governmental authorities (Ibragimova, 2012). It should be stressed that small business entities are getting special support if they are engaged in the development of new science-intensive technologies, innovations and export to external 
markets. Small business is a prime investment and innovational factor and economic growth driver, in its region, it is supported federally and regionally.

Business development in any region is traditionally considered a priority of state policy. To enhance business activity in Russian regions under national business initiatives, it is provided for to create the conditions for sustainable progressive development, business activity and investment activity as the basis for regional quality of life improvement and production enhancement. As assessed by Expert group of Agency for strategic initiatives, currently 85 regions joined the implementation of regional investment standard, 70 roadmaps were drafted and 85 expert groups on standard's implementation were formed. Regional investment standard includes 15 best investment practices used by the most economically successful regions. In most regions, including Bashkortostan and Tatarstan Republics, as assessed by Expert group, all 15 sections of the said standard were implemented in pilot mode and regional Investment strategy is monitored (Investment climate of the RF. Agency for strategic initiatives, 2015).

As the analysis of system documents shows, the investment standard assesses the expected business contribution in the regional development using the following indicators:

- growth of small and medium business stake in the total economic turnover:

- large-scale growth of high-tech production;

- formation of favorable investment climate creating the conditions for stable and balanced regional economic development;

- increase of highly productive modern jobs;

- enhancement of human potential quality and life quality;

- production output increase;

- growth of regional production competitiveness;

- growth of average individual income;

- investments in fixed capital accumulated during the period;

- growth rate of investments in fixed capital accumulated during the period.

Those indicators reflect the changing economic development of a region due to business investment activity, innovational response of production sphere to scientific and technological progress achievements; allow to detect gross regional product decrease risks or region's ability to independent solving of socio-economic problems.

To assess the economic activity of business, is it offered to use a set of coefficients united into three groups: manufacturing, innovative and socio-economic. Choosing and reasoning of the following parameters were as follows: quantity-based; calculations done under statistical reports (availability of information); visual expression and semantic content; simple formulae, etc. (Mukhametova, 2013).

The first coefficient is coefficient of manufacturing activity calculated by the formula:

$k_{1}=\frac{h_{1}}{b_{1}+m_{1}}$

where $k_{1}$ - coefficient of manufacturing activity;

$h_{1}$ - volume of shipped products/completed services or works, million rubles;

$b_{1}-$ costs on production and sales, million rubles;

$m_{1}$ - investments in fixed capital, million rubles.

The second coefficient of innovation activity is found by the formula:

$k_{2}=\frac{h_{2}}{b_{2}{ }^{+} m_{2}}$

where $k_{2}$ - coefficient of innovation activity;

$h_{2}$ - volume of innovative products/services/works, million rubles;

$b_{2}$ - costs on technological innovations, million rubles;

$m_{2}-$ costs on fundamental and applied R\&D, million rubles.

The third coefficient of socio-economic activity is calculated as under:

$k_{3}=\frac{m_{3}}{h_{3}-b_{3}}$

where $k_{3}$ - coefficient of socio-economic activity; 
$h_{3}$ - population income (average per capita per month), rubles;

$b_{3}$ - population expenses (average per capita per month), rubles;

$m_{3}-$ nominal average wages per worker, rubles

The level of economic activity of business in a region is found as the product of all coefficients offered:

$K_{E A}=\sqrt[3]{k_{1} \times k_{2} \times k_{3}}$

The manufacturing activity criterion characterizes the state of business material and engineering facilities in a region, its potential abilities to manufacture and efficiently use some kinds of products. The more products are made with the least costs, the more active the regional business is from the industry's point of view. Commercial production activity growth evidences the investments growth for the purpose to expand or renew regional production sector.

The innovation activity coefficient is calculated as the ratio of innovative products, scientific/engineering works and services completed per unit of costs on technological innovations and R\&D. Results of innovation activity are most frequently assessed by the number of registered discoveries by science branches, number of inventions, patents and author's certificates, as well as working samples of new developments. The current practice also allows to see the innovation activity dynamics by absolute values on $R \& D$ and by ratio to gross regional product which enables finding the intensity of scientific and engineering activity in a region.

The socio-economic activity coefficient is the ratio of average monthly wages per worker to the value of the difference between population incomes and population expenses. That coefficient is calculated based on a suggestion that the higher its value, the less the social distress, the more attractive region becomes for investors, migrants and the more opportunities for the solving of social problems. Efficient practice shows that the higher the welfare of population of a region, i.e., regional quality of life, the more opportunities to attract people's savings as investments for startups and venture projects. High level of population's socio-economic activity in a region may be considered a new tool for small and medium business development on crowd funding platform.

Thus, the comprehensive criterion for economic activity of business accounts for various aspects of regional economy reflecting the level of need for innovations, potential opportunities for development of production capacities of large and medium business and crown funding of small and social business.

\section{Results}

Economic activity of business was analyzed taking as examples the two leading regions of Volga federal district of the Russian Federation: Bashkortostan Republic (BR) and Tatarstan Republic (TR) (Table 1) (Small and medium business in Russia, 2014 and Regions of Russia. Socio-economic data, 2014).

As follows from Table 1, the indicators reflecting manufacturing activity of business in the said regions are decreasing. In 2011-2013, there was a decrease in manufacturing potential in those regions which may evidence the shortening of manufacturing business scale, investments in renewal or expansion of production facilities of enterprises and organizations.

However, in innovation coefficient group, innovation activity is growing expressed both as the volume of innovative products and costs on technological innovations, fundamental and applied research. The coefficient of innovation activity in TR grew from 3.6 in 2011 to 4.32 in 2013. In Bashkortostan Republic it decreased from 3.06 to 2.93. In the meantime, there are some positive dynamics in costs on technological innovations in 2012 with further growth in 2013 in the regions analyzed. Therefore, both in TR and BR it is required to take stimulating measures to expand the innovation activity.

In the world practice, the share of internal costs on R\&D is calculated as ratio to gross domestic product. As known for 2012, that indicator is 1.12 \% in Russia, 3.41\% in Sweden, 2.98\% in Germany. For Bashkortostan Republic it is 0.6\%, for Tatarstan Republic it is $0.72 \%$ (Russia and world's countries, 2014).

Table 1 - Indicators of economic activity of business in BR and TR in 2011-2013

\begin{tabular}{|c|c|c|c|c|c|c|}
\hline \multirow{2}{*}{ Indicator } & \multicolumn{2}{|c|}{2011} & \multicolumn{2}{|c|}{2012} & \multicolumn{2}{|c|}{2013} \\
\hline & BR & TR & BR & TR & BR & TR \\
\hline \multicolumn{7}{|l|}{ Manufacturing activity indicators } \\
\hline Products shipped/services and works completed, million rubles $\left(h_{1}\right)$ & 1421402 & 1345307 & 1507276 & 1467981 & 1205816 & 1549157 \\
\hline Costs on production and sales, million rubles $\left(b_{1}\right)$ & 831463 & 824763 & 877088 & 887003 & 923907 & 947852 \\
\hline Investments in fixed capital, million rubles $\left(m_{1}\right)$ & 188507 & 393569 & 232873 & 470751 & 266233 & 520228 \\
\hline Coefficient of manufacturing activity $\left(\mathrm{k}_{1}\right)$ & 1.39 & 1.1 & 1.35 & 1.07 & 1.01 & 1.05 \\
\hline
\end{tabular}




\begin{tabular}{|c|c|c|c|c|c|c|}
\hline \multicolumn{7}{|l|}{ Jation activity indicators } \\
\hline Volume of innovative products, works, services, million rubles $\left(h_{2}\right)$ & 58249 & 195969 & 62171 & 272574 & 74682 & 322320 \\
\hline Costs on technologic innovations, million rubles $\left(\mathrm{b}_{2}\right)$ & 13754 & 44166 & 12754 & 38101 & 18460 & 64437 \\
\hline Costs on fundamental and applied R\&D, million rubles $\left(\mathrm{m}_{2}\right)$ & 5306 & 8314 & 6880 & 9572 & 7036 & 10174 \\
\hline Coefficient of innovation activity $\left(\mathrm{k}_{2}\right)$ & 3.06 & 3.6 & 3.17 & 5.7 & 2.93 & 4.32 \\
\hline \multicolumn{7}{|l|}{ Social activity indicators } \\
\hline Population income (average per capita per month), rubles $\left(h_{3}\right)$ & 19030 & 20223 & 21259 & 24004 & 23892 & 26161 \\
\hline Population expenses (average per capita per month), rubles $\left(b_{3}\right)$ & 15743 & 16322 & 17412 & 19217 & 19632 & 21130 \\
\hline Nominal average wages per worker, rubles $\left(\mathrm{m}_{3}\right)$ & 18397 & 20009 & 20264,7 & 23234 & 22377 & 26035 \\
\hline Coefficient of social activity $\left(\mathrm{k}_{3}\right)$ & 2.38 & 5.1 & 5.2 & 4.9 & 5.2 & 5.2 \\
\hline Region's economic efficiency criterion (KEA) & 2.2 & 2.7 & 2.8 & 3.1 & 2.5 & 2.9 \\
\hline $\begin{array}{l}\text { Number of enterprises and organizations for 100,000 of economically } \\
\text { active population (as on the end of year) }\end{array}$ & 389 & 509 & 419 & 527 & 457 & 562 \\
\hline \multicolumn{7}{|l|}{ Small business indicators } \\
\hline Number of small enterprises, thousand & 32.4 & 45.9 & 38.9 & 47.9 & 40.8 & 49.6 \\
\hline Turnover of small enterprises, billion rubles & 480.2 & 504.4 & 536.7 & 622.9 & 598.3 & 707.3 \\
\hline Average number of small business employees, thousand people & 258.5 & 324.0 & 299.3 & 332.0 & 301.1 & 330.4 \\
\hline
\end{tabular}

Social activity coefficients in the analyzed regions have stabilized for the recent three years. The regions possess some socio-economic potential for financing small business and social business on crowd-funding platform. Economic activity of business may grow throughout co-financing projects by population.

Comparative analysis of regions allowed to find that the comprehensive criterion of economic activity of business and comprising coefficients of manufacturing, innovation and social activity in Tatarstan Republic are mainly higher than those related to Bashkortostan Republic. Number of enterprises and organizations for 100,000 of economically active population is also higher in Tatarstan Republic. Volume of innovative products in that region as well as costs on technological innovations are higher compared to Bashkortostan Republic - over 5 times. Socio-economic indicators of business activity got closer by 2013. Therefore, Tatarstan Republic is in the lead compared to Bashkortostan Republic in economic development including innovations. It is important to stress that business structures notable for the use of new technologies and large costs on fundamental and applied R\&D are occupying the top positions in value chain, able to control design and most production operations located in various parts of the country and abroad.

The dynamics of small business indicators in those regions during the period analyzed are repeating the trend of changing economic activity indicators. Small business indicators acknowledge its higher activity in Tatarstan Republic compared to Bashkortostan Republic.

In the investment attractiveness rating, Bashkortostan Republic and Tatarstan Republic have average investments potentials followed by minimal level of investments risk: in BR -0.196 (risk rank dropped by 6 points within a year), in TR - 0.183 (rating growing by 4 points) (Investment attractiveness of regions - 2014: management burden. Expert rating agency, 2014). Therefore, the level of economic activity in the regions observed is also statistically average.

Development of business activity in the Russian regions is hindered by various reasons which are mainly typical for all:

- low availability of resources (labor market tightening, real estate limitedness, long time on land title registration, insufficiency of regional budget funds for stimulation of business activity;

- instability and inconsistence of the current regulations (tax, small business employees protection), legal ignorance of entrepreneurs;

- missing positive image of national businessmen;

- administrative environment and large business are not friendly enough to small business;

- no real production development, downturn in sectoral demand;

- high tax barriers and first of all, insurance costs;

- $\quad$ high costs on fuel and energy due to unfavorable natural and climatic conditions; transportation costs; power infrastructure connection costs.

\section{Discussion}

Current macroeconomic instability, worsening geopolitical situation, no national economic growth, depletion of traditional resources and methods ensuring economic stability and sustainable development are all calling for greater increase of business's role as a prime investment and innovation factor and regional economic activity driver. 
In connection with the development of a set of measures on governmental support and regulation of business it is feasible to assess the grade of their interrelation with the contribution made by business to the regional tax potential and with the regional budget's income level.

Reasoning of assessment indicators describing business contribution in regional sustainable economic development is shown in Table 2. The system of assessment parameters is based on value added, which is the result of economic activity, assesses incomes of those employed by enterprises/organizations and business incomes (Sharipova, \& Mukhametova, 2014).

Value added is created at all the stages of production chain: extraction of raw materials, production, distribution and delivery of material and by-flows from product manufacturer to end-users. The amount of value added of all sector's enterprises forms gross value added showing the total output of products and services less intermediate consumption not including the value of fixed capital. Gross value added of all sectors and branches in the country is the gross domestic product at the manufacturing stage, in the region - gross regional product. System of national accounts includes in value added the cost of labor of employed population, depreciation charge, profit of enterprises/organizations, rent received by them, interest and, above all, net export.

Table 2 - System of assessment indicators of business contribution to regional economic development

\begin{tabular}{|c|c|c|c|c|}
\hline Indicator & Logics & \multicolumn{3}{|c|}{ Concerns } \\
\hline CVA - cumulative value added & $\begin{array}{l}\text { Level of cumulative value added created in the } \\
\text { course of business }\end{array}$ & \multirow{2}{*}{\multicolumn{3}{|c|}{$\begin{array}{ll}- & \text { Gross regional product growth (GRP) } \\
- & \text { Growing economic activity in production networks } \\
- & \text { Improvement of economic structure due to changing } \\
- & \text { business specialization } \\
- & \text { Growing budget income } \\
- & \text { Development of hi-tech production } \\
- & \text { Creating comfortable place to live and do business } \\
- & \text { High grade of welfare in the region and social stability }\end{array}$}} \\
\hline$B E_{R}-$ budget efficiency & $\begin{array}{l}\text { Efficient observance of governmental business } \\
\text { regulation }\end{array}$ & & & \\
\hline CTB - tax burden coefficient & Ability of business to fulfill tax liabilities & 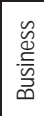 & & $\begin{array}{l}\text { Improvement of inter-industrial interaction quality } \\
\text { Enhancement of business cooperation infrastructure } \\
\text { Optimization (decrease) of trading, transportation, } \\
\text { communication costs }\end{array}$ \\
\hline
\end{tabular}

Cumulative value added is the total amount of value added created by all preceding links of production chain while creating material/product flows for an estimated sector. In the contemporary economy, not all the links of value chain are present on the regional level. Most stages of value added creation are located outside any company or region.

Calculation of cumulative value added will ensure finding region's economic activity level, capital accumulation of business entities in branches and sectors of the regional economy.

It is offered to calculate the volume of change (gain) of value added within a certain branch created in that region's territory using the following formula:

$$
\Delta C V A=\sum_{i, j=1}^{n}\left(G V A_{j}-k_{i} \times G V A_{i} \times \tau\right) \Rightarrow \max
$$

where $\triangle C V A$ - gain of cumulative value added created in the course of production of estimated $j$ sector;

$G V A_{j}$ - value added of estimated $j$ sector;

$G V A_{i}$ - value added of preceding $i$ sector;

$k_{i}$ - stake of intermediary costs of $i$ sector spent in the course of manufacturing products of $j$ sector;

$\tau$ - number of intermediaries by stages of technological chain creating value added of estimated $j$ sector;

$n$ - number of estimated sectors in value added chain.

Value added accumulation during delivery of products from $i$ processing sector to final processing $n$ sector, where ready-to-use products are made is overlapping with value chain. The more processing stages of primary materials are completed in a region, the higher is the gain of cumulative value added created by the region's business.

Cumulative value added change may be used to find budget and financial ratios established by regional business sector. It is possible to establish rational proportions between operational budgets and development budgets of basic constituent entities, regional budget and financial relations. Gain maximization criterion CVA is used for stimulation by regional authorities of priority directions for basic economic sectors. Cumulative value added may be increased by regional policy on enhancement of innovation activity and human and fixed capital quality improvement.

To find the tax burden, it is offered to calculate coefficients of tax burden and budget efficiency. Tax burden 
calculation is based on accounting for all tax amounts paid by business including indirect taxes integrated into product price.

Tax burden coefficient allows to assess incomes paid to federal and regional budgets. This is the financial component of cumulative value added CVA, which determines the volume of regional budget replenishment and business self-financing. Under regional financial deficiency and heavy competition for financial resources, the applicable regional taxation system is of practical importance in connection with investment climate formation.

Tax burden coefficient is calculated per separate links of value added chain:

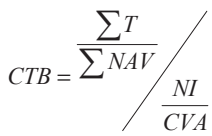

where CTB - tax burden coefficient;

$\sum T-\operatorname{tax}$ burden (total taxes);

$\sum N A V$ - net assets value;

CVA - cumulative value added calculated as the sum of value added gains in the course of manufacturing products by estimated $j$ sector;

$\mathrm{NI}$ - net profit.

$$
C V A=\sum_{i=1}^{n} \Delta G V A_{i}
$$

Tax burden coefficient allows to assess contribution of business to the regional tax potential.

Budget efficiency coefficient reflects the rate of return on governmental support of business. That coefficient was developed accounting for the guidelines on assessment of investment projects efficiency and their shortlisting for financing (approved by Gosstroy (State Committee of the Russian Federation for Construction, Architectural and Housing Policy), Ministry of Economy of the RF, Ministry of Finance of the RF, Goskomprom (State Committee of the Russian Federation for Industrial Policy) dated March 31, 1994).

Budget efficiency characterizes the rate of return of the regional budget financed from business revenues:

$$
B E_{R}=\left(\sum R B_{S B}-\sum D I C_{S B}\right) / \sum D I C_{S B} \times \frac{1}{1+r}
$$

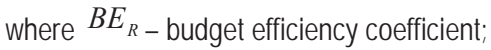

$\sum R B_{S B}$ - total budget revenue received from business;

$\sum D I C_{S B}$ - total direct and indirect costs on business support;

$r$ - policy rate of Central Bank of the RF in target year.

Comparing budget revenues and expenses with policy rate of Central Bank of the RF is conditioned by the need to account for missed profit due to optional financial investments in banks instead of business projects. The suggested formula (8) allows to assess budget efficiency of business support in upcoming sectors from the point of view of their involvement in value chain.

One of the possible solutions for active regional development is the integration of region's economy into global and national value added chains. That is due to the fact that the contemporary economy is more and more specializing not in production of goods and services but in objectives and functions of business. The value chain consists of the following business functions: design, marketing, production, distribution, after-sale service. Depending on business localization level, availability of resource suppliers, manufacturers and end-users, business is competing for a particular position in value added chain. Growing involvement of business in global and national value added chains exerts great positive influence on the economic development of both region and country due to active participation of regional business in various links of value chain beginning with primary products extraction and ending with transformation into final consumer product.

Accounting for participation of regional enterprises and organizations in global/national value chains, regional budget revenues include:

- taxes paid to budget from regional business;

- decrease/increase of tax returns from companies engaged in global/national value added chain;

- dividends on securities of companies engaged in global/national value added chain held by the RF constituent entities;

- income tax on salaries of employees engaged in global/national value added chain;

- tax returns to budget for use of natural resources paid by companies engaged in global/national value added 
chain;

Regional budget expenses may include:

- direct financing of business project budgets engaged in global/national value added chain;

- bank loans facilitated to Russian/foreign participants of global/national value added chain;

- direct budget allocations granted on support of priority sectors engaged in global/national value added chain;

- payments in connection with governmental securities;

- compensations paid by budget under preferential insurance contracts to companies engaged in global/national value added chain;

- governmental and regional risk guarantees granted to Russian/foreign participants of global/national value added chain.

In the international practice, value added is calculated using international input-output tables which allow to analyze global production chains, determine the position of business sector in interstate format. Therefore, to determine country's position in international value added chains, Russia returned to the official statistical input-output balance practice to account for and prognosticate key macroeconomic parameters. Input-output tables are made in compliance with the provisions of System of national accounts every five years on a regular basis, according to the world's practice. The use of statistical database greatly improves the quality of analysis and tools for governmental and regional control and regulation of economy. To obtain the current assessments of business's participation in the regional economic development it is feasible to apply current indicators of value added dynamics.

Origin, dynamics, target of value added created by regional business structures may be identified using the system of indicators established on the basis of cumulative value added and by-coefficients.

One of the possible solutions of regional economy's sustainable development in current situation is the integration of regional economy into global and national value added chains. Assessment of the volume of value added created and accumulated in a region will enable the analysis and regulation of regional economy's structure and establishment of financial proportions. It will become possible to solve the issues in connection with regional competitiveness, economic growth, innovative development throughout enhancement of economic activity of business in production networks.

During a crisis, methodological guidelines on choosing areas of governmental support of regional business may be formed on the basis of its participation in innovational and investment intensive links of value added chain.

Practical significance of this research is in theoretical and applied aspects, development of recommendations for regional control authorities on selection of socially minded and economically feasible priorities of the regional policy for business stimulation oriented at investments and innovations in a region. The methodology established allows to make a differential assessment of business's contribution in the regional economy accounting to created value added factors, budget and tax efficiency.

The statistical database available allows to analyze the structures of value added by regions of the Russian Federation (RF). We chose two regions of Volga federal district of the Russian Federation - Bashkortostan Republic (BR) and Tatarstan Republic (TR). For the analysis, published data of Rosstat (Federal State Statistics Service) for 2012 was used (Table 3) (Regions of Russia. Socio-economic data, 2014 and Republic Bashkortostan by numbers, 2014).

Table 3 - Sectoral structure of gross value added of Russia, Volga federal district, BR and TR in 2011-2012, \%

\begin{tabular}{|c|c|c|c|c|c|c|c|c|}
\hline \multirow{2}{*}{ Parameter } & \multicolumn{4}{|c|}{2011} & \multicolumn{4}{|c|}{2012} \\
\hline & \begin{tabular}{|l|l}
$\mathrm{RF}$ \\
\end{tabular} & VFD & BR & TR & RF & VFD & $B R$ & TR \\
\hline \multicolumn{9}{|l|}{ Infrastructure unit } \\
\hline Infrastructure production facilities and services: & 15.7 & 14.5 & 12.3 & 12.1 & 15.6 & 13.9 & 11.6 & 11 \\
\hline Power generation, gas and water & 4.2 & 4.3 & 3.3 & 2.9 & 3.8 & 3.8 & 2.7 & 2.5 \\
\hline Transport and communications & 10.1 & 9.3 & 8.1 & 8.2 & 10.4 & 9.1 & 7.9 & 7.5 \\
\hline Other utilities, social and personal services & 1.4 & 0.9 & 0.9 & 1 & 1.4 & 1 & 1 & 1 \\
\hline \multicolumn{9}{|l|}{ Production unit } \\
\hline Industry: & 29 & 37 & 38.8 & 39.2 & 28.5 & 37.5 & 40.1 & 39.6 \\
\hline Mineral wealth mining & 11.2 & 12.6 & 4.8 & 22.2 & 11.2 & 12.5 & 2.9 & 21.3 \\
\hline Manufacturing & 17.8 & 24.4 & 34 & 17 & 17.3 & 25 & 37.2 & 18.3 \\
\hline Construction & 7 & 7.2 & 7.3 & 10.3 & 7.1 & 7.2 & 7.4 & 10.4 \\
\hline Agriculture, forestry and fishing & 4.9 & 7.1 & \begin{tabular}{|l|l|}
7.7 & \\
\end{tabular} & 7.1 & 4.4 & 6.1 & \begin{tabular}{|l|}
5.6 \\
\end{tabular} & 6 \\
\hline Agriculture, hunting and forestry & 4.7 & 7.1 & 7.7 & 7.1 & 4.2 & 6.1 & 5.6 & 6 \\
\hline Fishing, fish-farming & 0.2 & 0 & 0 & 0 & 0.2 & 0 & 0 & 0 \\
\hline
\end{tabular}




\begin{tabular}{|l|c|c|c|c|c|c|c|c|}
\hline Service unit & $\mathbf{3 2 . 1}$ & $\mathbf{2 3}$ & $\mathbf{2 2 . 6}$ & $\mathbf{2 4 . 3}$ & $\mathbf{3 1 . 7}$ & $\mathbf{2 3 . 4}$ & $\mathbf{2 3 . 8}$ & $\mathbf{2 5 . 5}$ \\
\hline Services: & 19.4 & 13.3 & 14.5 & 13.7 & 18.2 & 13.5 & 15.2 & 15.1 \\
\hline Retail and wholesale; vehicle/motorcycle/personal items repair & 11.1 & 8.2 & 6.5 & 9.2 & 11.9 & 8.5 & 7.2 & 9 \\
\hline Real estate operations, lease and services & 0.6 & 0.5 & 0.4 & 0.5 & 0.6 & 0.4 & 0.3 & 0.4 \\
\hline Financial business & 1 & 1 & 1.2 & 0.9 & 1 & 1 & 1.1 & 1 \\
\hline HoReCa & 11.3 & 11.2 & 11.3 & 7 & 12.7 & 11.9 & 11.5 & 7.5 \\
\hline Public goods: & 4.7 & 4.4 & 3.6 & 2.5 & 5.6 & 4.9 & 3.8 & 2.9 \\
\hline National administration and military security; social insurance & 2.9 & 3.1 & 3.9 & 2.4 & 3.1 & 3.2 & 3.7 & 2.5 \\
\hline Education & 3.7 & 3.7 & 3.8 & 2.1 & 4 & 3.8 & 4 & 2.1 \\
\hline Healthcare and social services & & &
\end{tabular}

Upon the analysis of value added structure, three sectoral units were distinguished:

- Infrastructure unit, comprising power generation, gas and water; transport and communications; other utilities, social and personal services;

- Production unit, comprising mining and manufacturing; construction; agriculture, forestry and fishing;

- Service unit, comprising services and public goods;

In the infrastructure unit it was found that: in country in general the highest share of value added falls on transport and communications (10.4\%), insignificant share falls on other utilities, social and personal services (1.4\%). Comparing two constituent entities of the RF (BR and TR), the following may be observed: sectors' share in creation of value added by regions differs insignificantly. In Tatarstan, there is a well operating transport network comprising airlines, highways and railways. Tatarstan's geographic position determines its key role in transport links of Eastern and Western Russia and communication lines with other countries. Bashkortostan Republic is crossed by highways and pipelines. By air, Bashkortostan is connected with dozens of cities in Russia, the CIS and Greece, China, the UAE, Turkey.

In the production unit it was found that in the regions analyzed the structure of created value differs inside industry. In Bashkortostan Republic there is a higher share of manufacturing in value added than in Tatarstan Republic. For instance, the share of manufacturing in 2011-2012 was about 34-37\% of Bashkortostan Republic's gross regional product, $17-18.3 \%$ of that of Tatarstan Republic. The average country's level of that parameter was $17.3 \%$, in Volga federal district $-25 \%$. In mining sector, to the contrary, value added in Tatarstan Republic exceeds that in Bashkortostan Republic. The share of value added in mineral wealth mining in TR is higher than the average Russia's level.

Rural sector plays an important part in Tatarstan Republic's economy. Tatarstan Republic is in top-three Russian regions in agricultural output. Bashkortostan Republic's agriculture is mainly grain-growing and animal farming. The share of agriculture in gross value added by constituent entities differs insignificantly (Bashkortostan Republic - 5.6\%; Tatarstan Republic-6\%).

Retail and wholesale business structures are actively engaged in the course of value added creation: in Bashkortostan $-15.2 \%$, in Tatarstan $-15.1 \%$, average in Volga federal district $-13.5 \%$, average in Russia $-18.2 \%$. Meantime, business activity in trade is twice as high as in construction. However, low activity of business in infrastructure and service is noted. In the studied regions, the share of infrastructure sectors is lower than the average Russia's level.

Among services, retail and wholesale as well as HoReCa began developing greatly in the contemporary conditions both in the country and in its constituent entities. It is required to enhance financial business on both levels.

In public goods, Bashkortostan Republic has the higher share compared to Tatarstan Republic. It may be explained by the availability of many educational institutions, multinational population, education in various spheres, healthcare system (commercial and non-commercial at option).

Meantime, population is supported in a number of various ways by government in form of subsidies for utility services and socially. In both constituent entities of Volga federal district the living conditions for people and general activation of socio-economic potential are favorable.

Thus it was found out that the highest contribution of business in gross regional product in the analyzed constituent entities was made by industry.

\section{Conclusions}

The system of assessment indicators for business contribution to regional economic activity allows to define the role of agents, sectors, operating in the region, in ensuring its sustainable and long-term development, creating more jobs, due payments to budget.

Practical application of the system of indicators offered for measuring economic activity of regional business 
ensures the following:

- assessing real situation in the regional economy;

- finding the most exposed spheres in each unit of the system of regional economy's sustainable development indicators;

- reasoning the priority of restructuring measures, i.e., optimization of region's development;

- forecasting regional economy in the short and long run in the event of any principal measures in connection with economic restructuring in that region.

Further improvement of system of assessment indicators for economic activity of business based on cumulative value added in a region will let to eliminate the awkwardness of system of national accounts and improve the methodology for assessment of regional economy's sustainable development for more adequate view of its condition.

Involvement of business structures in value added chain on the regional level will allow to optimize the structure of economy in a region and give recommendation on business engagement in GRP via governmental order/procurement systems. Assessment of business contribution via change (gain) of cumulative value added will enable to work out Strategy of industrial and innovational development of a region, tactic for forming budget and financing proportions in regional economy.

Regional value chain creation management suggests business involvement and programs for socio-economic development of a territory. Special attention should be paid to the following priorities: sectoral ratings designating links/sectors with high value added creation; assessment of import replacement potential;

assessment of opportunities to be part of national and global value added chains; forming financing and economic proportions in a region.

Economic activity of business on one hand reflects the state of regional economy: innovational development level, potential opportunities for production on large and medium business level, crowd-funding prospects for small and social business.

On the other hand, in the course of working out comprehensive measures on state support and development of business sector it is required to find the interrelation of regional budget revenues and business contribution to tax potential of a constituent entity of the RF to determine the least competitive economy's sectors.

\section{References}

Ács, Z., Autio, E., \& László, S. (2014). National Systems of Entrepreneurship: Measurement issues and policy implications. Research Policy, 3(43), 476-494.

Anokhin, S., \& Schulze, W. (2009). Entrepreneurship, innovation, and corruption. Journal of Business Venturing, 5(24), 465-476.

Galindo, M., \& Méndez, M. (2014). Entrepreneurship, economic growth, and innovation: Are feedback effects at work? Journal of Business Research, 5(67), 825-829.

Simón-Moya, V., Revuelto-Taboada, L., \& Guerrero, R. (2014). Institutional and economic drivers of entrepreneurship: An international perspective. Journal of Business Research, 5(67), 715-721.

Toma, S., Grigore, A., \& Marinescu, P. (2014). Economic Development and Entrepreneurship. Procedia Economics and Finance, 8, 436443.

Jennings, P., Greenwood, R., Lounsbury, M., \& Suddaby, R. (2013). Institutions, entrepreneurs, and communities: A special issue on entrepreneurship. Journal of Business Venturing, 1(28), 1-9.

Dragan, I., \& Isaic-Maniu A. (2012). The Entrepreneurship Impact on the Dynamic of Macroeconomic Results. Procedia Economics and Finance, 3, 515-520.

Jones, M., Coviello, N., \& Tang, Y. (2011). International Entrepreneurship research (1989-2009): A domain ontology and thematic analysis. Journal of Business Venturing, 6(26), 632-659.

Kanniainen, V., \& Vesala, T. (2005). Entrepreneurship and labor market institutions. Economic Modelling, 5(22), 828-847.

Eckhardt, J., \& Shane, S. (2003). Opportunities and Entrepreneurship. Journal of Management, 3(29), 333-349.

Avdasheva, S., Budanov, I., Golikova, V., \& Yakovlev, A. (2005). Modernization of Russian enterprises in value chains (as exemplified by pipe and furniture sectors of Russia). Economic journal of Higher school of economics, 3, 361-377.

Agency for strategic initiatives. (2015). Investment climate of the RF. Retrieved April 22, 2015, from http://investstandart.ru.

Akhtarieva, L., \& Veleyeva, E. (2014). Tool for regional image management and its assessment. Economics and management, 2, 45-50.

Grishin, K., \& Arapov, V. (2013). Tools for detecting business growth points in regions based on administrative regulation optimization. Economy of region, 4, 150-157.

Ibragimova, N. (2012). Cluster approach as an efficient tool for public-private partnership development. Bulletin of Ufa state academy of economics and service, 1, 111-115.

Kaplinskiy, R. (2002). Expansion of globalization's positive effect. Which conclusions can be made by analyzing value added chain? 
Trans. Preprint WP5 /2002 /3. Moscow: HSE.

Malikov, R., \& Kharisov, V. (2013). Development of tools for assessment of realization risks of business development infrastructure projects. Economics and management, 4, 199-207.

Small and medium business in Russia. 2014. (2014). Moscow: Rosstat.

Regions of Russia. Socio-economic data. 2013. P 32. (2014). Moscow: Rosstat.

Bashkortostan Republic in numbers: Complex bulletin. In 2 parts. P. 1, P. 2. (2014). Ufa: Bashkortostanstat.

Russia and world's countries. 2014. (2014). Moscow: Rosstat.

Mukhametova, D. (2013). Assessment of regional economy's development stability. Economics and management, 3, 75-79.

Solodilova, N., Malikov, R., \& Grishin, K. (2014). Generation of favorable institutional configuration of regional business environment. Economics and management, 4, 271-282.

Sharipova, I., \& Mukhametova, D. (2014). Growth of business contribution in sustainable development of regional economy. Economics and management, 2, 51-55.

Expert Rating Agency (RAEX). (2014). Investment attractiveness of regions - 2014: management burden. Retrieved April 222, 2015, from http://raexpert.ru/ratings/regions/2014. 